\title{
Genetic patterns of the corals Euphyllia glabrescens and Lobophyllia corymbosa across the Indonesian Archipelago
}

\author{
JAMALUDDIN JOMPA ${ }^{1, \bullet}$, WIDYASTUTI UMAR ${ }^{2, \bullet \bullet}$, SYAFYUDDIN YUSUF $^{1}$, \\ ASMI CITRA MALINA AR. TASSAKKA ${ }^{1}$, GINO V. LIMMON ${ }^{3}$, RAHMI $^{4}$, AMANDA PRICELLA PUTRI ${ }^{2}$, \\ HALWI ${ }^{2}$, HARTATI TAMTI ${ }^{5}$, ABIGAIL MARY MOORE ${ }^{1}$ \\ ${ }^{1}$ Faculty of Marine Science and Fisheries, Universitas Hasanuddin. Jl. Perintis Kemerdekaan Km. 10, Tamalanrea, Makassar 90245, South Sulawesi, \\ Indonesia. Tel.: +62-411-586025, `email: j.jompa@unhas.ac.id \\ ${ }^{2}$ Center of Excellence for Interdisciplinary and Sustainability Science, Graduate School, Universitas Hasanuddin. Jl. Perintis Kemerdekaan Km. 10 \\ Tamalanrea, Makassar 90245, South Sulawesi, Indonesia. Tel.: +62- 411-585868, `email: widyastuti160@ gmail.com \\ ${ }^{3}$ Faculty of Fisheries and Marine Science, Universitas Pattimura. Jl. Mr. Chr. Soplanit, Poka, Ambon 97234, Maluku, Indonesia \\ ${ }^{4}$ Faculty of Agriculture, Universitas Muhammadiyah Makassar. Jl. Sultan Alauddin No. 259, Makassar 90221, South Sulawesi, Indonesia \\ ${ }^{5}$ Sekolah Tinggi Teknologi Kelautan Balik Diwa. Jl. P. Kemerdekaan VIII No. 8, Tamalanrea, Makassar 90245, South Sulawesi, Indonesia
}

Manuscript received: 25 February 2020. Revision accepted: 13 May 2020.

\begin{abstract}
Jompa J, Umar W, Yusuf S, Tassakka ACM, Limmon GV, Rahmi, Putri AP, Halwi, Tamti H, Moore AM. 2020. Genetic patterns of the corals Euphyllia glabrescens and Lobophyllia corymbosa across the Indonesian Archipelago. Biodiversitas 21: 24922499. Scleractinian corals can reproduce in several ways, with two main sexual reproduction modes known as brooding and broadcast spawning. In this study, we described patterns of genetic variation within and connectivity between coral populations in western Indonesia (Seribu Archipelago), central Indonesia (Spermonde Archipelago), and eastern Indonesia (Ambon). We sampled two readily identifiable corals popular in the marine aquarium trade, one species widely reported as a brooder (Euphyllia glabrescens), the other as a broadcast spawner (Lobophyllia corymbosa). The mitochondrial COI genome was amplified for 117 samples. Within-population genetic variation was high, especially at the eastern Indonesia (Ambon) site. The genetic connectivity patterns were similar for the two corals, with high connectivity between the Seribu and Spermonde Archipelagos (despite a geographical separation of more than 1,000 km) and a lack of connectivity between these two sites and Ambon. These results indicate a potential barrier to gene flow between coral populations in western/central Indonesia and those to the east of Sulawesi Island.
\end{abstract}

Keywords: Brooder, connectivity, mitochondrial DNA, scleractinian corals, spawner

\section{INTRODUCTION}

Coral reefs are tropical marine ecosystems with exceptionally high productivity and biodiversity (Barber et al. 2011; Carpenter et al. 2011; Rinkevich 2015; Wooldridge 2017). Reef-forming (scleractinian) corals have an important role in life underwater as well as for the many human communities which depend on the ecosystem services they provide (Hoegh-Guldberg et al. 2019; Woodhead et al. 2019). However, the condition of coral reefs is in decline, due to many disrupting factors, most of which are related to direct and indirect anthropogenic activities such as the effects of destructive fishing, increased nutrient concentrations and pollution due to landbased activities, sedimentation, marine debris, anthropogenic climate change, and ocean acidification, all of which threaten their geo-ecological and provisioning functions (Green et al. 2014; Hoegh-Guldberg et al. 2019; Wooldridge 2017; Perry and Filip 2019; Woodhead et al. 2019). Marine tourism can also pose threats to coral reefs, not only from direct damage (e.g. trampling, diver contact and boat anchors), but also from increased prevalence of coral disease and coral bleaching caused by sunscreens containing substances toxic to corals (Lamb et al. 2014; Gill et al. 2015; Kurniawan et al. 2016; Sharifan 2020).
There is a growing consensus that conservation initiatives for the maintenance and restoration of coral populations and coral reef ecological communities require both passive and active approaches (Rinkevich 2014, 2015; Zayasu and Shinzato 2016; Fox et al. 2019; Perry and Filip 2019; Bostrom-Einarsson et al. 2020). Passive (also called natural) restoration relies on the removal of causal factors to reverse ecosystem degradation through spontaneous regeneration (e.g. recruitment of coral larvae); in addition, active (or assisted) restoration involves direct human action to "correct abiotic and biotic damage and trigger biotic recovery" (Gann et al., 2019), for example, the provision of substrate and planting of coral propagules (BostromEinarsson et al. 2020). However, in order for such interventions to succeed, it is vital to consider the potential geospatial and biological connectivity between coral populations (Kool et al. 2011; Treml and Halpin 2012). Knowledge of dispersal distances and distribution paths on an ecological time scale is important because it will provide information about the potential for recovery of damaged coral reef populations (Treml and Halpin 2012). Recovery can occur through the re-growth of coral colonies and fragments of surviving colonies, as well as through new recruitment from local and external sources (Lukoschek et al. 2013; Bostrom-Einarsson et al. 2020). 
However, although some adult coral colonies may appear to be able to withstand severe disruptions, their presence does not guarantee coral recruitment and many factors can affect the reproductive success and settlement of corals (Ritson-Williams et al. 2009; Teichberg et al. 2018; Fox et al 2019).

The connectivity of a coral species will be directly influenced by its intrinsic dispersal capacity as well as environmental factors (Chust et al. 2016; Riegl et al. 2019). Biological connectedness of different populations of a given organism can be evaluated through the proportions of certain genetic characters or traits present in each population (Selkoe et al. 2016) and could also be influenced by specific biological traits (Keyse et al. 2014). The relationship between the dispersal capacity during certain life phases and genetic differentiation can provide fundamental insights into ecological and evolutionary relationships (Riginos et al. 2014).

There are two common sexual reproduction modes in scleractinian corals: sexual reproduction with internal fertilization (brooders) and with external fertilization (spawners); these different types of reproduction can affect the potential dispersal distance of coral larvae from their reef of origin during the planktonic phase (Thomas et al. 2019). However, there are many other factors which can influence the dispersal distance including the length of time for which the larvae can remain viable (competent), their ability to float in the water column, physical oceanographic conditions, and the availability of suitable substrate (Baums et al. 2005; Goodbody-Gringley and de Putron 2016).

Although tracking the movement of larvae in the sea directly is extremely difficult, a growing number of studies have estimated the distribution patterns and distances of biological material using molecular approaches (Keyse et al. 2014; von der Heyden et al. 2014; Liggins et al. 2016). Studies on scleractinian corals include the work of Nakajima et al. (2010) who found high connectivity between populations of the coral Acropora digitifera along the $1,000 \mathrm{~km}$ island chain of the Nansei Archipelago, Japan. Scleractinian corals are considered as good model organisms to study, because they can reveal patterns directly influenced by the spatial dispersal distance (Thomas et al. 2019). Coral recruitment tends to occur locally if the larval planktonic period is very short, as is commonly the case in species with internal fertilization (brooders). Conversely, the distance traveled by coral larvae tends to be greater for corals with longer planktonic periods, such as those typically observed in broadcast spawning species (Hellberg 1994; Serrano et al. 2016).

This study aimed to describe genetic connectivity patterns in Indonesian waters of two coral species widely reported as belonging to the two different reproductive guilds: Euphyllia glabrescens (brooder, Fan et al. 2006; Petersen et al. 2007; Ayop et al. 2017; Luzon et al. 2017) and Lobophyllia corymbosa (spawner, Harriott 1983; Floos et al. 2012). Recent observations confirmed the respective reproductive strategies of these two coral species in the Spermonde Archipelago, South Sulawesi, Indonesia
(Syafyuddin Yusuf, pers. com., 2018). Both species are widespread, readily recognizable corals traded commercially in the marine ornamental trade. We investigated the biological patterns of genotypic diversity, genetic flow, and population structure. Information on the connectivity patterns of these two corals should help to support effective conservation management.

\section{MATERIALS AND METHODS}

\section{Specimen collection and storage}

Samples of the putative brooding coral Euphyllia glabrescens and putative broadcast spawning coral Lobophyllia corymbosa were collected during August and September 2018 from three regions. These were: western Indonesia (Java) represented by the Seribu Archipelago (Pramuka Island), central Indonesia represented by the Spermonde Archipelago (Barrang Lompo and Badi Island) close to the west coast of Sulawesi, and eastern Indonesia, represented by Ambon Island. Coral fragments $(n \geq 30)$ were collected for each species from each location. To avoid potentially confounding factors affecting genetic variation such as depth and other habitat condition parameters, sampling was carried out in the same depth range (3-10 meters) at each location. Coral fragments were collected with a minimum distance of 2 meters between donor colonies in order to minimize the likelihood of collecting clones produced from the same colony through fragmentation. The collected samples were preserved in 96$100 \%$ absolute ethanol and stored at room temperature (transport and short term) or in a refrigerator set to a temperature of $4^{\circ} \mathrm{C}$ (for storage periods exceeding 3 months).

\section{Genome DNA extraction, polymerase chain reaction (PCR) and electrophoresis}

Standard Qiagen Blood and Tissue Kits were used for DNA extraction of both coral types. As the corals used in this study have hard physical structures, lysis was conducted overnight to facilitate the process of DNA extraction (Umar et al. 2019a, 2019b). The DNA template obtained from the extraction process was then amplified through PCR with 38 cycles. The protocol used followed by Umar et al. (2019a, 2019b). The primers used to amplify a segment of the COI mitochondrial genome (mtDNA) are shown in Table 1.

The PCR product was then screened using electrophoresis on agarose gel $(0.75 \mathrm{~g}$ agarose $1 \%$ gel dissolved in $75 \mathrm{~mL}$ SL Buffer with $4 \mu \mathrm{L}$ ethidium bromide powder as a fluorescent agent) at $100 \mathrm{~V} / 400$ amps for 30 minutes. The DNA band was observed under UV light. The protocol used followed by Umar et al. (2019a). The successfully amplified samples (Table 2) were sent to Macrogen (Netherlands) and Berkeley (USA) sequencing centers for Sanger sequencing. 
Table 1. Primer pairs used to amplify coral COI mtDNA

\begin{tabular}{lcc}
\hline Species & Forward & Reverse \\
\hline Lobophyllia corymbosa & mt COI & mt COI \\
& CAGG CGCT ATGT TAGG AGATG & CCCG CTAA TACA GGCA AAG ATA \\
Euphyllia glabrescens & Cs-F18 5, & Cs-R18 5, \\
& GGACACAAGAGCATATTTTACTG & CTACTTACGGAATCTCGTTTGA \\
\hline
\end{tabular}

Table 2. Amplified coral COI mtDNA samples.

\begin{tabular}{lcc}
\hline \multicolumn{1}{c}{ Site } & \multicolumn{2}{c}{ Amplified } \\
\cline { 2 - 3 } & $\begin{array}{c}\text { L. corymbosa } \\
\text { (spawner) }\end{array}$ & $\begin{array}{c}\text { E. glabrescens } \\
\text { (brooder) }\end{array}$ \\
\hline $\begin{array}{l}\text { Seribu Archipelago (Pramuka } \\
\text { Island) }\end{array}$ & 28 & 30 \\
Spermonde Archipelago (Badi & 32 & 14 \\
$\begin{array}{l}\text { and Barrang Lompo Islands) } \\
\text { Ambon }\end{array}$ & 6 & 7 \\
Total & 66 & 51 \\
\hline
\end{tabular}

\section{Genetic analyses}

The genetic analyses implemented were: (i) haplotype distribution by population/site; (ii) genetic population structure; (iii) paired between-site genetic distances. Initial editing of the nucleotide base sequences was performed in MEGA 6.0 (Molecular Evolutionary Genetics Analysis) (Tamura et. al. 2013). The sequences were aligned and trimmed to produce a set of clean aligned sequences for each coral species which were exported in FASTA format. These sequences were 470 bp long for the spawner $L$. corymbosa and $938 \mathrm{bp}$ for the brooder E. glabrescens. The FASTA sequences were analyzed in DNASP (DNA Sequence Polymorphism) software (Rozas et al. 2003) to obtain the haplotype distribution in each population. Analysis of Molecular Variance (AMOVA) statistical calculations was performed in Arlequin 3.0 (Excoffier et al. 2005).

\section{RESULTS AND DISCUSSION}

\section{Allelic variation}

The allelic diversity of the $938 \mathrm{bp}$ brooder coral sequences and 470 bp spawner coral sequences (Table 3) showed that haplotype diversity was highest in the samples collected from Ambon $(H d=1)$ for both brooding and broadcast spawning corals. Haplotype diversity of one can have two very different interpretations. One is the possibility of high-stress levels resulting in genetic variation as a survival mechanism. The other is that a large amount of diverse genetic material may enter the waters of the study site which could result in high recruitment at the study site with opportunities for high levels of genetic variation between recruits. The latter could be considered likely, due to the geographical conditions of Ambon, with potential apports of genetic material (competent larvae) from several directions.

The geographical distribution of the haplotypes (Figure 1) shows that, for both E. glabrescens and L. corymbosa, the most common alleles in the Seribu Archipelago and Spermonde populations were the same. All haplotypes present at the Ambon site were unique to this location for both coral species.

The two most common E. glabrescens haplotypes (numbered 1 and 2) were the same in the Seribu and Spermonde Archipelagos. Together, these two haplotypes comprised $89 \%$ of the samples sequenced from these two sites. Five haplotypes were represented by one sample, three from the Seribu Archipelago (numbered 3 to 5), and two from the Spermonde Archipelago (numbered 6 and 7), the remaining seven haplotypes being unique to Ambon.

For L. corymbosa, two dominant haplotypes (numbered 1 and 2) represented $80 \%$ of samples from the Seribu and Spermonde Archipelagos. All haplotypes from the Spermonde Archipelago were present in the Seribu Archipelago, with five additional haplotypes in the Seribu Archipelago sample. The remaining six haplotypes were unique to Ambon.

Allelic variability and genotypic diversity can be used to evaluate the relative contribution of sexual and asexual reproduction to the local population (Boulay et al. 2012). The observed genetic variation at each of the three sites indicates a high level of genotypic diversity even at very small geographical scales, indicating that sexual reproduction is the predominant mode of reproduction for both coral species in this study.

Table 3. Observed genetic variation of three Euphyllia glabrescens and Lobophyllia corymbosa populations

\begin{tabular}{llccc}
\hline Species (reproductive guild) & \multicolumn{1}{c}{$\begin{array}{c}\text { Collection } \\
\text { site }\end{array}$} & $\begin{array}{c}\text { Number of haplotypes } \\
\text { (\#hap })\end{array}$ & $\begin{array}{c}\text { Haplotype diversity } \\
(\boldsymbol{H d})\end{array}$ & $\begin{array}{c}\text { Nucleotide diversity } \\
(\boldsymbol{\pi})\end{array}$ \\
\hline E. glabrescens & Seribu Archipelago & 5 & 0.404 & 0.000 \\
(brooder) & Spermonde Archipelago & 4 & 0.494 & 0.001 \\
& Ambon & 7 & 1.000 & 0.347 \\
L. corymbosa & Hd Total & 9 & $\mathbf{0 . 5 7 4}$ & \\
(spawner) & Seribu Archipelago & 4 & 0.727 & 0.009 \\
& Spermonde Archipelago & 6 & 0.544 & 0.005 \\
& Ambon & & 1.000 & 0.575 \\
\hline
\end{tabular}




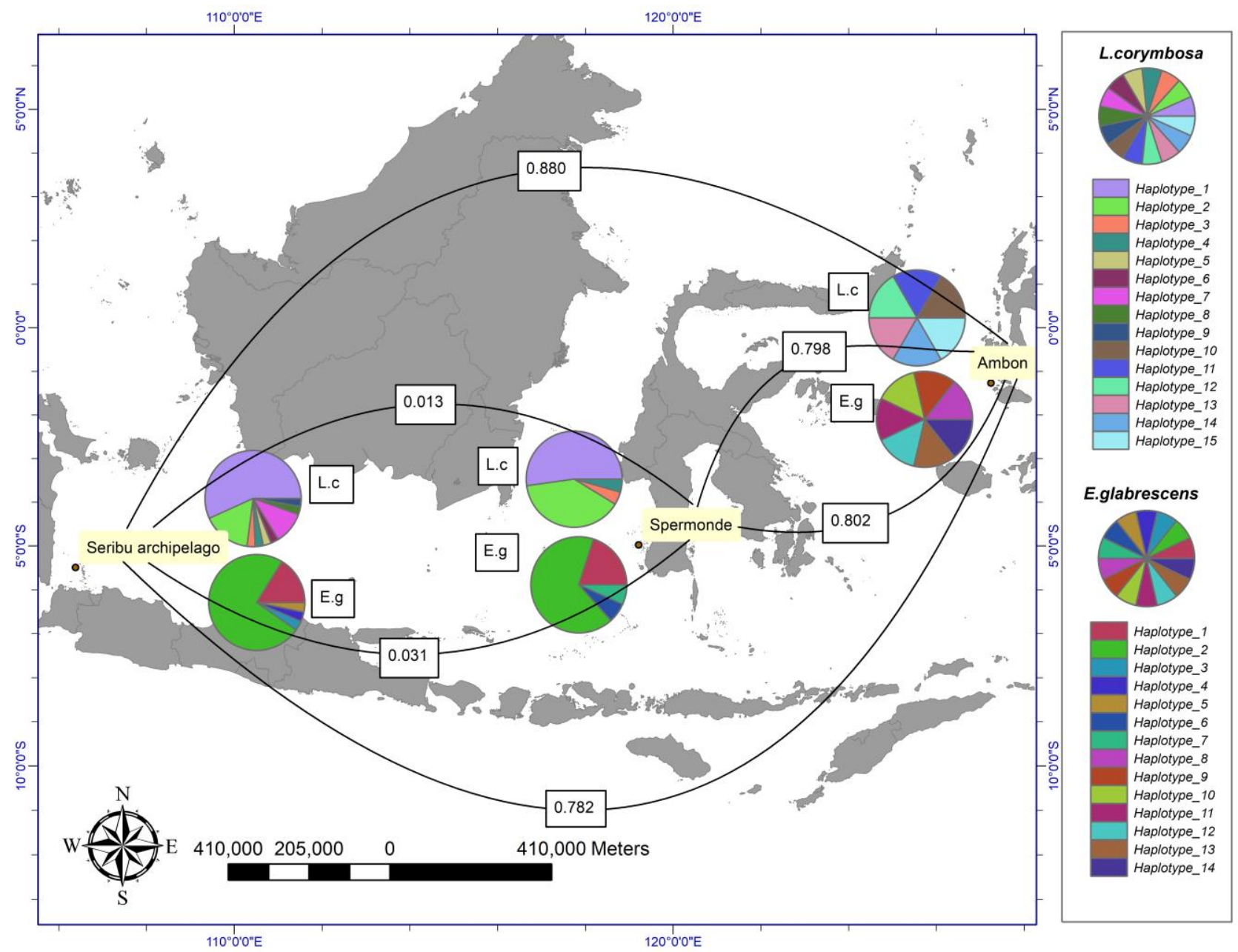

Figure 1. Geographic distribution of Euphyllia glabrescens (putative brooder) and Lobophyllia corymbosa (putative spawner) haplotypes and pairwise genetic distances between the three study sites (L.c=L. corymbosa, E.c=E. glabrescens).

\section{Fine-scale population structure}

The overall $\mathrm{F}_{S T}$ value for both E. glabrescens and $L$. corymbosa showed a low level of genetic connectivity across Indonesia (Table 4). The respective $\mathrm{F}_{S T}$ values of around 0.8 and 0.65 imply that geography has a strong influence on genetic traits present in coral populations at the study locations.

\section{Pairwise between population gene flow}

Our study found a striking pattern in the pairwise genetic distance values between the three populations for both E. glabrescens and L. corymbosa (Table 5). The genetic distance between coral populations in the Seribu Archipelago and Spermonde was low for both $E$. glabrescens (0.019) and L. corymbosa (0.031). These low genetic distances indicate a high value of genetic connectivity with significant gene flow between the two sites. In contrast, the genetic distance between the Ambon population and the other two populations was high for both corals, although the geographical distance between the Seribu and Spermonde Archipelagos is less than that from the Spermonde Archipelago to Ambon (Figure 1), indicating limited gene flow and thus low connectivity.

\section{Genetic structure}

The extent to which coral populations are effectively linked to each other is a topic of considerable interest in coral science, in particular, the potential of any given population to function as a source of larvae to promote recovery from external disturbance at other sites (Ayre and Hughes 2004; Trapon et al. 2011; Thomas et al. 2019). Larval dispersal plays an important role in the dynamics of populations and communities of marine organisms such as reef fishes (Liggins et al. 2016) and corals (RitsonWilliams et al. 2009). Understanding coral connectivity patterns, sources of recruitment, and the implications of coral reproductive strategies are very important for policymakers (Hellberg 2007; Thomas et al. 2019). Reproductive strategy (brooder versus spawner) could influence the distribution of genetic material at locations separated by considerable geographical distances and result in different connectivity patterns. 
Table 4. F $_{S T}$ values of E Euphyllia glabrescens and Lobophyllia corymbosa for the three study sites (AMOVA estimates)

\begin{tabular}{|c|c|c|c|c|c|}
\hline & Source of variation & d.f & Sum of Squares & Variance components & Percentage of variation \\
\hline \multirow[t]{4}{*}{ E. glabrescens } & Among population & 2 & 2661.141 & $91.701 \mathrm{Va}$ & 80.940 \\
\hline & Within Population & 48 & 1036.310 & $21.590 \mathrm{Vb}$ & 19.060 \\
\hline & Total & 50 & 3697.451 & & \\
\hline & Fixation index $\left(\mathrm{F}_{S T}\right)$ & & & 0.8 & \\
\hline \multirow[t]{4}{*}{ L. corymbosa } & Among population & 2 & 1010.955 & $25.831 \mathrm{Va}$ & 65.020 \\
\hline & Within Population & 63 & 875.469 & $13.896 \mathrm{Vb}$ & 34.980 \\
\hline & Total & 65 & & & \\
\hline & Fixation index $\left(F_{S T}\right)$ & & & 0.65 & \\
\hline
\end{tabular}

Table 5. Pairwise population genetic distance of three Euphyllia glabrescens and Lobophyllia corymbosa populations

\begin{tabular}{|c|c|c|c|c|}
\hline & Sites & Seribu Archipelago & Spermonde & Ambon \\
\hline \multirow[t]{3}{*}{ E. glabrescens } & Seribu Archipelago & $*$ & & \\
\hline & Spermonde & 0.019 & $*$ & \\
\hline & Ambon & 0.881 & 0.798 & $*$ \\
\hline \multirow[t]{3}{*}{ L. corymbosa } & Seribu Archipelago & * & & \\
\hline & Spermonde & 0.031 & $*$ & \\
\hline & Ambon & 0.782 & 0.802 & $*$ \\
\hline
\end{tabular}

This study revealed an unexpected pattern of genetic connectivity common to both $E$. glabrescens and $L$. corymbosa. Pairwise genetic distances close to zero for populations in the Seribu and Spermonde Archipelagos indicate strong genetic connectivity between populations of both species over a large geographical area $(>1000 \mathrm{~km})$ from northwestern Java to southwest Sulawesi. Conversely, the high paired $F_{S T}$ values (Table 5) between the Ambon populations and those in the Spermonde and Seribu Archipelagos show a high level of genetic differentiation. The observed values are sufficient to indicate extremely limited genetic flow (Holsinger and Weir 2015).

The genetic distance between two of the three populations was not significant for either coral species, although the genetic distance was lower for the brooding coral E. glabrescens than the spawning coral L. corymbosa (Table 5). This is the reverse of the pattern which could be expected based on the generally shorter dispersal distances of brooding coral larvae compared to broadcast spawned larvae (Lugo-Fernandez 2001) and reports of significantly different genetic connectivity patterns between brooding and spawning corals (Thomas et al. 2019). However, studies comparing the dispersal competence of brooder and spawner corals in the Caribbean (Serrano et al. 2016), on the Great Barrier Reef (Ayre and Hughes 2004) and the Red Sea (Maier et al. 2009) also found that differences in reproductive mode do not appear to inhibit coral dispersion.

The high genetic similarity indicates strong connectivity between the western and central Indonesian sites, which may both belong to a common metapopulation sensu Hellberg (2007). One possible explanation for this observed connectivity pattern could be the direction and rate of surface currents as carriers and connectors of biological material from one location to another. Specifically, there are seasonal surface currents flowing from the Seribu Archipelago through the Java Sea corridor (Durand and Petit 1995; Barber et al. 2011) which could connected to the Flores Sea current and enter the Makassar Strait, or at least the southern reaches of the Strait where the Spermonde Archipelago is sited, as well as from the Makassar Strait into the Java Sea. The strong connectivity between the sites in the Seribu Archipelago and Spermonde may indicate that larvae of both coral species can disperse over the considerable distances involved, possibly through rare but evolutionarily significant events as proposed by Carpenter et al. (2011). Alternative explanations include the stepping stone theory (Hellberg 2007), with gene flow transmitted through geographically intermediate populations. These could be extant populations with ongoing gene flow or "ghosts of dispersal past" (Crandall et al. 2014).

\section{Potential barrier to dispersal}

The high genetic exchange between the Seribu and Spermonde Archipelagos for both corals studied is in stark contrast to the apparent lack of genetic exchange between these two areas and Ambon. The lack of an observable difference in connectivity between corals with different reproductive strategies indicates that some mechanism other than larval dispersal distance underlies the betweensite genetic distances. While a genetic break observed in just one species could result from demographic or sampling artefacts, co-occurring genetic breaks in more than one taxon tend to indicate general barriers to connectivity (Hellberg 2007). Thus the similarity of the patterns 
observed for the two coral species indicates the possible presence of a barrier to dispersal somewhere between the Ambon site and the two other sites (Spermonde and Seribu Archipelagos), most likely north of the Wakatobi Archipelago which has strong connectivity with the Spermonde Archipelago for L. corymbosa (Umar et al. 2019b)

The high heterogeneity in Ambon populations for both corals in this study is consonant with the predictions of the model developed by Kool et al. (2011) that "The Flores, Banda and Ceram seas, as well as Halmahera are expected to accumulate high levels of diversity on the basis of present-day migration currents". Fine scale genetic divergence in coral reef organisms has been observed in complex small island groups (e.g. Timm et al. 2017). The complex oceanographic features in the Banda Sea region around Ambon could provide suitable conditions to support genetic differentiation, for example through divergent selection (Bowen et al. 2013).

The notion of a fragmented population structure, such as that reported for the Caribbean (Holstein et al. 2014), is supported by the results of Umar et al. (2019a,b) for $L$. corymbosa populations around Sulawesi. While high levels of connectivity were found between four sites (Umar et al. $2019 \mathrm{~b}$ ), the unexpected patterns reported in Umar et al. (2019a) indicate limited connectivity and/or connectivity with a different metapopulation for the Banggai site in East Sulawesi. The four sites in Umar et al. (2019b), in waters to the north, west and south of Sulawesi, are potentially linked by current flows, at least at certain seasons. As noted by Moore et al. (2019), fine-scale data for the waters east of Sulawesi (Gulf of Tolo and Banda Sea) are limited, but indicate potentially complex current and larval dispersal patterns; furthermore, very few studies on genetic population structure have included sites within this area, a fact that may account for the apparent lack of reported connectivity barriers. This absence is in contrast to the many putative barriers reported in the seas to the north, south and west of this area (e.g. Carpenter et al. 2011; Treml et al. 2015; Crandall et al. 2014). However, Barber et al. (2011) report divergence between central and eastern Indonesia in some stomatopod populations. Further research is required to elucidate the connectivity patterns of spawning and brooding corals (and other reef-associated organisms) in this region, and test the barrier hypothesis.

\section{Conservation management perspectives and future research}

Many population genetic studies claim conservation benefits arising from genetic data, although they are often difficult to interpret (Karl et al. 2012; von der Heyden et al. 2014). The incorporation of molecular data into conservation management and planning can be a challenging process (Taylor et al. 2017), mainly due to the lack of theoretical and practical frameworks (Nielsen et al. 2017). However, integrating genetic information is very important both to describe the population and to provide insight regarding genetic connectivity within and between populations and metapopulations (Hellberg 2007; Barber et al. 2011; von der Heyden 2017; Yusuf et al. 2019; Umar et al. 2019c). The observed genetic connectivity patterns for E. glabrescens and L. corymbosa, two corals with different reproductive strategies, may well apply to many other species of coral and reef-associated organisms. There are many aspects calling for future research, including to strengthen and clarify understanding of the fundamental differences in dispersal and genetic connectivity between corals of both reproductive guilds; on the enabling mechanisms and timescales of connection or isolation between coral populations in geographically separated locations; and to evaluate the influence of geographical and local influences on within population genetic variation.

\section{ACKNOWLEDGEMENTS}

We gratefully acknowledge research funding from the Indonesian Ministry for Research and Higher Education (Kemenristekdikti) and in-kind assistance with sample analysis from Prof. Marc Kochzius (Vrije Universiteit, Brussels, Belgium). We thank Samsul, Fajar, Iqram, Aliah and Arida for their assistance in the field and laboratory.

\section{REFERENCES}

Ayop AN, Sotto FB, Wagas EC. 2017. Diel timing and lunar periodicity of larval release by the caryophyllid coral, Euphyllia glabrescens in the Central Philippines. In: Dautova TN, Sun X, Sun S, Adrianov AV (eds.). Life-Supporting Asia-Pacific Marine Ecosystems, Biodiversity and Their Functioning. Science Press, Beijing.

Ayre DJ, Hughes TP. 2004. Climate change, genotypic diversity and gene flow in reef-building corals. Ecol Lett 7: 273-278. DOI: 10.1111/j.1461-0248.2004.00585.x

Barber PH, Cheng SH, Erdmann MV, Tenggardjaja K, Ambariyanto. 2011. Evolution and conservation of marine biodiversity in the Coral Triangle: Insights from stomatopod Crustacea. In: Held C, Koenemann S, Schubar CD (eds.). Phylogeography and Population Genetics in Crustacea. CRC Press, Boca Raton.

Baums IB, Miller MW, Hellberg ME. 2005. Regionally isolated populations of an imperilled Caribbean coral, Acropora palmata. Mol Ecol 14: 1377-1390. DOI: 10.1111/j.1365-294X.2005.02489.x

Bostrom-Einarsson L, Babcock RC, Bayraktarov E, Ceccarelli D, Cook N, Ferse SCA, Hancock B, Harrison P, Hein M, Shaver E, Smith A, Suggett D, Stewart-Sinclair PJ, Vardi T and Mcleod IM. 2020. Coral restoration - A systematic review of current methods, successes, failures and future directions. PLoS One 15: 1-24. DOI: 10.1371/journal.pone.0226631.

Boulay JN, Cortés J, Nivia-Ruiz J and Baums IB. 2012. High genotypic diversity of the reef-building coral Porites lobata (Scleractinia: Poritidae) in Isla del Coco National Park, Costa Rica. Revista de Biología Tropical 60: 279-292.

Bowen BW, Rocha LA, Toonen RJ, Karl SA. 2013. The origins of tropical marine biodiversity. Trends Ecol Evol 28: 359-366.

Carpenter KE, Barber PH, Crandall ED, Ablan-Lagman MCA, Ambariyanto, Mahardika GN, Manjaji-Matsumoto BM, Juinio-Menez MA, Santos MD, Starger CJ, Toha AHA. 2011. Comparative phylogeography of the coral triangle and implications for marine management. J Mar Biol 396982: 1-14.

Chust G, Villarino E, Chenuil A, Irigoien X, Bizsel N, Bode A, Broms C, Claus S, Fernández de Puelles ML, Fonda-Umani S, Hoarau G, Mazzocchi MG, Mozetič P, Vandepitte L, Veríssimo H, Zervoudaki S, Borja A. 2016. Dispersal similarly shapes both population genetics and community patterns in the marine realm. Sci Rep 6: 28730.

Crandall ED, Treml EA, Liggins L, Gleeson L, Yasuda N, Barber PH, Wörheide Ga, Riginos C. 2014. Return of the ghosts of dispersal past: Historical spread and contemporary gene flow in the blue sea star Linckia laevigata. Bull Mar Sci 90: 399-425. 
Durand JR, Petit D. 1995. The Java Sea Environment. In: Potier M Nurhakim S (eds) Biodynex: Biology, dynamics, exploitation of the small pelagic fishes in the Java Sea. Agency for Agricultural Research and Development, Jakarta.

Excoffier L, Laval G, Schneider S. 2005. Arlequin ver. 3.0: An integrated software package for population genetics data analysis. Evol Bioinformatic 1: 47-50.

Fan TY, Lin KH, Kuo FW, Soong K, Liu LL, Fang LS. 2006. Diel patterns of larval release by five brooding scleractinian corals. Mar Ecol Prog Ser 321: 133-42. DOI: 10.3354/meps321133.

Floos YA, Al-Sofyani AA and Zari TA. 2012. Sexual reproduction of two reef building corals Seriatopora hystrix and Lobophyllia corymbosa in the Jeddah coast of Red Sea. Biosci Biotech Res Asia 9 (1): 63-72.

Fox HE, Harris JL, Darling ES, Ahmadia GN, Estradivari and Razak TB 2019. Rebuilding coral reefs: Success (and failure) 16 years after lowcost, low-tech restoration. Rest Ecol 27: 862-869. DOI: 10.1111/rec. 12935 .

Gann GD, McDonald T, Walder B, Aronson J, Nelson CR, Jonson J, Hallett JG, Eisenberg C, Guariguata MR, Liu J, Hua F, Echeverría C, Gonzales E, Shaw N, Decleer K, Dixon KW. 2019. International principles and standards for the practice of ecological restoration. Second edition. Society for Ecological Restoration, Washington, D.C, USA.

Gil MA, Renfro B, Figueroa-Zavala B, Penie I, Dunton KH. 2015. Rapid tourism growth and declining coral reefs in Akumal, Mexico. Mar Biol 162: 2225-2233. DOI: 10.1007/s00227-015-2748-z.

Goodbody-Gringley G, de Putron SJ. 2016. Brooding Corals: Planulation Patterns, Larval Behavior, and Recruitment Dynamics in the Face of Environmental Change. In: Goffredo S, Dubinsky Z. (eds.). The Cnidaria, Past, Present and Future. Springer, Cham.

Green AL, Fernandes L, Almany G, Abesemis R, Mcleod E, Aliño PM, White AT, Salm R, Tanzer J, Pressey RL. 2014. Designing marine reserves for fisheries management, biodiversity conservation, and climate change adaptation. Coast Manag 42: 37-41. DOI: 10.1080/08920753.2014.877763

Harriott VJ. 1983. Reproductive ecology of four scleratinian species at Lizard Island, Great Barrier Reef. Coral Reefs 2: 9-18. DOI: /10.1007/BF00304727

Hellberg ME. 1994. Relationship between inferred levels of gene flow and geographic distance in a philopatric coral Balanophyllia elegans Evolution 48: 1829-1854. DOI: 10.1111/j.1558-5646.1994.tb02218.x

Hellberg ME. 2007. Footprints on water: The genetic wake of dispersal among reefs. Coral Reefs 26: 463-473. DOI: 10.1007/s00338-0070205-2

Hoegh-Guldberg O, Pendleton L, Kaup A. 2019. People and the changing nature of coral reefs. Reg Stud Mar Sci 30: 1-20.

Holsinger KE, Weir BS. 2015. Genetics in geographically structured populations: Defining, estimating and interpreting $F_{S T}$. Nat Rev Genet 10: 639-650.

Holstein DM, Paris CB, Mumby PJ. 2014. Consistency and inconsistency in multispecies population network dynamics of coral reef ecosystems. Mar Ecol Prog Ser 499: 1-18.

Karl SA, Toonen RJ, Grant WS, Bowen BW. 2012. Common misconceptions in molecular ecology: Echoes of the modern synthesis. Mol Ecol 21 (17): 4171-4189.

Keyse J, Crandall ED, Toonen RJ, Meyer CP, Treml EA, Riginos C. 2014 The scope of published population genetic data for Indo-Pacific marine fauna and future research opportunities in the region. Bull Mar Sci 90: 47-78. DOI: 10.5343/bms.2012.1107

Kool JT, Paris CB, Barber PH, Cowen RK. 2011. Connectivity and the development of population genetic structure in Indo-West Pacific coral reef communities. Global Ecol Biogeogr 20: 695-706. DOI: 10.1111/j.1466-8238.2010.00637.x.

Kurniawan F, Adrianto L, Bengen DG, Prasetyo LB. 2016. Vulnerability assessment of small islands to tourism: The case of the Marine Tourism Park of the Gili Matra Islands, Indonesia. Global Ecol Conserv 6: 308-326. DOI: 10.1016/j.gecco.2016.04.001

Lamb JB, True JD, Piromvaragorn S, Willis BL. 2014. Scuba diving damage and intensity of tourist activities increases coral disease prevalence. Biol Conserv 178: 88-96. DOI 10.1016/j.biocon.2014.06.027.

Liggins L, Treml EA, Possingham HP, Riginos C. 2016. Seascape features, rather than dispersal traits, predict spatial genetic patterns in co-distributed reef fishes. J Biogeogr 43: 256-267. DOI: 10.1111/jbi. 12647
Lugo-Fernandez A. 2001. Inferring probable dispersal of Flower Garden Banks coral larvae (Gulf of Mexico) using observed and simulated drifter trajectories. Continental Shelf Res 21: 47-67.

Lukoschek V, Cross P, Torda G, Zimmerman R, Willis BL. 2013. The Importance of coral larval recruitment for the recovery of reefs impacted by cyclone Yasi in the Central Great Barrier Reef. PLoS One 8 (6): e65363. DOI: 10.1371/journal.pone.0065363.

Luzon KS, Lin MF, Lagman MC, Licuanan WR, Chen CA. 2017 Resurrecting a subgenus to genus: Molecular phylogeny of Euphyllia and Fimbriaphyllia (order Scleractinia; family Euphylliidae; clade V). PeerJ 5: e4074. DOI: 10.7717/peerj.4074.

Maier E, Tollrian R, Nuernberger B. 2009. Fine-scale analysis of genetic structure in the brooding coral Seriatopora hystrix from the Red Sea. Coral reefs 28: 751-756.

Moore AM, Tassakka ACM, Ambo-Rappe R, Yasir I, Smith DJ, Jompa J. 2019. Unexpected discovery of Diadema clarki in the Coral Triangle. Mar Biodivers 49: 1-19.

Nakajima Y, Nishikawa A, Iguchi A, Sakai K. 2010. Gene flow and genetic diversity of a broadcast-spawning coral in northern peripheral populations. PLoS One 5 (6): e11149. DOI: 10.1371/journal.pone.0011149.

Nielsen ES, Beger M, Henriques R, Selkoe KA, von der Heyden S. 2017. Multispecies genetic objectives in spatial conservation planning. Conserv Biol 31: 872-882.

Perry CT, Filip LA. 2019. Changing geo-ecological functions of coral reefs in the Anthropocene. Funct Ecol 33: 976-988.

Petersen D, Falcato J, Gilles P, Jones R. 2007. Sexual reproduction of scleractinian corals in public aquariums: Current status and future perspectives. Intl Zoo Yearbook 41 (1): 122-37. DOI: 10.1111/j.17481090.2007.00006.x

Riegl B, Johnston M, Glynn PW, Keith I, Rivera F, Vera-Zambrano M, Banks S, Feingold J, Glynn PJ. 2019. Some environmental and biological determinants of coral richness, resilience and reef building in Galápagos (Ecuador). Sci Rep 9: 10322. DOI: 10.1038/s41598019-46607-9

Riginos C, Buckley YM, Blomberg SP, Treml EA. 2014. Dispersal capacity predicts both population genetic structure and species richness in reef fishes. The America Naturalist 184 (1): 52-64. DOI: 10.1086/676505.

Rinkevich B. 2014. ScienceDirect Rebuilding coral reefs: Does active reef restoration lead to sustainable reefs? Curr Opin Environ Sustain 7: 2836. DOI: 10.1016/j.cosust.2013.11.018.

Rinkevich B. 2015. Novel tradable instruments in the conservation of coral reefs, based on the coral gardening concept for reef restoration. J Environ Manag 162: 199-205. DOI: 10.1016/j.jenvman.2015.07.028

Ritson-Williams R, Arnold SN, Fogarty ND, Steneck RS, Vermeij MJ, Paul VJ. 2009. New perspectives on ecological mechanisms affecting coral recruitment on reefs. Smithsonian Contrib Mar Sci 38: 437-457.

Rozas J, Sanchez-DeI BJC, Messeguer, Rozas XR. 2003. DnaSP, DNA polymorphism analyses by the coalescent and other methods. Bioinformatics 19: 2496-2497.

Selkoe KA, Aloia CCD, Crandall ED, Iacchei M, Liggins L, Puritz JB, von der Heyden S, Toonen RJ. 2016. A decade of seascape genetics: Contributions to basic and applied marine connectivity. Mar Ecol Prog Ser 554: 1-19.

Serrano X, Baums, I, Smith T, Jones RJ, Shearer TL, Baker AC. 2016. Long distance dispersal and vertical gene flow in the Caribbean brooding coral Porites astreoides. Sci Rep 6: 21619. DOI: $10.1038 /$ srep 21619

Sharifan H. 2020. Alarming the impacts of the organic and inorganic UV blockers on endangered coral's species in the Persian Gulf: A scientific concern for coral protection. Sustain Futures 2: 100017. DOI: $10.1016 /$ j.sftr.2020.100017.

Tamura K, Peterson D, Peterson N, Stecher G, Nei M, Kumar S. 2013. MEGA6: Molecular Evolutionary Genetics Analysis version 6.0. Mol Biol Evol 12: 2725-2729.

Taylor HR, Dussex N, van Heezik Y. 2017. Bridging the conservation genetics gap by identifying barriers to implementation for conservation practitioners. Global Ecol Conserv 10: 231-242.

Teichberg M, Wild C, Bednarz VN, Kegler, Hauke F, Lukman M, Gärdes AA, Heiden JP, Weiand L, Abu N, Nasir A, Miñarro S, Ferse SCA, Reuter H, Plass-Johnson JG. 2018. Spatio-temporal patterns in coral reef communities of the Spermonde Archipelago, In: Comprehensive Reef Monitoring of Water and Benthic Indicators Reflect Changes in Reef Health. Front Mar Sci 5: 1-18. 
Thomas L, Underwood JN, Adam AAS, Richards ZT, Dugal L, Miller KJ, Gilmour JP. 2019. Contrasting patterns of genetic connectivity in brooding and spawning corals across a remote atoll system in northwest Australia. Coral Reefs 35: 55-60.

Timm J, Kochzius M, Madduppa HH, Neuhaus AI. 2017. Small scale genetic population structure of coral reef organisms in Spermonde Archipelago, Indonesia. Front Mar Sci 4: 1-14.

Trapon ML, Pratchett MS, Penin L. 2011. Comparative effects of differen disturbances in coral reef habitats in Moorea, French Polynesia. J Mar Biol 201: 1-11.

Treml EA andHalpin PN. 2012. Marine population connectivity identifies ecological neighbors for conservation planning in the Coral Triangle. Conserv Lett 5: 441-449. DOI: 10.1111/j.1755-263X.2012.00260.x.

Treml EA, Roberts J, Halpin PN, Possingham HP, Riginos C. 2015. The emergent geography of biophysical dispersal barriers across the IndoWest Pacific. Divers Distrib 21: 465-476.

Umar W, Tassakka ACMAR, Barber PH, Jompa J. 2019a. Unexpected patterns of genetic connectivity in Lobophyllia corymbosa (Forskål, 1775) around Sulawesi, Indonesia. Biodiversitas 20: 2744-2749.

Umar W, Tassakka ACMAR, Jompa J. 2019b. High genetic connectivity in a scleractinian coral (Lobophyllia corymbosa) around Sulawesi, Indonesia. Biodiversitas 20: 3484-3492.

Umar W, Tassakka ACMAR, Jompa J. 2019c. Potential uses of genetic studies for MPA design. IOP Conf Ser Earth Environ Sci 253: 012032 . von der Heyden S, Beger M, Toonen RJ, Van Herwerden L, Juinio-Meñez MA, Ravago-Gotanco R, Fauvelot C, Bernardi G. 2014. The application of genetics to marine management and conservation: Examples from the Indo-Pacific. Bull Mar Sci 90: 123-158. DOI: 10.5343/bms.2012.1079.

von der Heyden S. 2017. Making evolutionary history count: Biodiversity planning for coral reef fishes and the conservation of evolutionary processes. Coral Reefs 36: 183-194.

Woodhead AJ, Hicks CC, Norström AV, Williams GJ, Graham, NAJ. 2019. Coral reef ecosystem services in the Anthropocene. Funct Ecol 33: 1023-1034.

Wooldridge SA. 2017. Instability and breakdown of the coral-algae symbiosis upon exceedence of the interglacial pCO2 threshold (>260 ppmv): The "'missing"” Earth-System feedback mechanism. Coral Reefs 36: 1025-1037.

Yusuf S, Ahmad M, Umar W, Limmon GV, Jompa J. 2019. Biogeography and diversity of Lobophyllia, an ornamental coral traded in the coral triangle. IOP Conf Ser Earth Environ Sci 253: 012030. DOI: $10.1088 / 1755-1315 / 253 / 1 / 012030$

Zayasu Y, Shinzato C. 2016. Hope for coral reef rehabilitation: Massive synchronous spawning by outplanted corals in Okinawa, Japan. Coral Reefs 35: 1295. DOI: 10.1007/s00338-016-1463-7. 